\title{
How do reproductive output, larval behaviour, and recruitment contribute to adult spatial patterns in Mediterranean encrusting sponges?
}

\author{
María-J. Uriz ${ }^{1, *}$, Manuel Maldonado ${ }^{1}$, Xavier Turon $^{2}$, Ruth Martí $^{1}$ \\ 'Centre d'Estudis Avançats (CSIC), Camí de Sta. Bàrbara s/n, E-17300 Blanes (Girona), Spain \\ ${ }^{2}$ Department of Animal Biology, Faculty of Biology, University of Barcelona, 645 Diagonal Ave, E-08028 Barcelona, Spain
}

\begin{abstract}
We studied the abundance and spatial pattern of 2 Mediterranean encrusting sponges, Crambe crambe (highly toxic) and Scopalina lophyropoda (non-toxic), at 4 spatial scales $(0.5,1,2$ and $4 \mathrm{~m}^{2}$ ). We also examined the reproductive output, larval behaviour and recruitment in these species, and assessed the relative importance of these parameters in explaining the abundance and spatial pat. terns of adults. We also determined, in field experiments, whether the presence of adults induces or inhibits recruitment in these 2 species. We found that $C$. crambe was much more abundant than $S$. lophyropoda at the site studied in both number of individuals per $\mathrm{m}^{2}(67 \pm 2.7 \mathrm{vs} 10.2 \pm 2.1$, mean $\pm \mathrm{SE}$ ) and coverage $(47 \pm 1.9$ vs $11.1 \pm 1.4 \%)$. At the smallest scale sampled $\left(0.5 \mathrm{~m}^{2}\right)$, both species showed an aggregated pattern. Aggregation was also detected for $S$. lophyropoda, but not for C. crambe, at the scales of 1 and $2 \mathrm{~m}^{2}$ The number of embryos incubated per $\mathrm{cm}^{2}$ by C. crambe and S. lophyropoda was $76.2 \pm 12.5$ and $14 \pm 1.7$ (mean \pm SE), respectively. We estimated that the potential number of larvae of C. crambe released into the water column was about 20 times higher than that of S. lophyropoda. Larval behaviour was monitored in the laboratory and in the field. Larvac of S. lophyropoda did not swim away from the release point. They maintained a vertical posture that minimised horizontal dispersal, and soon began crawling. In contrast, the larvae of C. crambe swam actively and had a comparatively delayed crawling phase. Recruitment of the 2 species in scraped quadrats surrounded by individuals of C. crambe and S. lophyropoda, and in controls (rocky areas with no sponges), was monitored weekly for a month. Recruitment of both species was higher in scraped quadrats surrounded by conspecifics. This effect was notably more marked for S. lophyropoda than for C. crambe recruits. The toxicity of $C$. crambe did not inhibit settlement of $S$. lophyropoda with respect to controls. The mean number of recruits per unit surface area after 1 mo (all substrates pooled) was ca 3.5 times higher for $C$. crambe than for $S$. lophyropoda. This difference was smaller than expected given that larval production of $C$. crambe was ca 20 times higher. This indicates that a significant proportion of C. crambe's offspring did not contribute to the maintenance of the local population. The aggregated pattern of $S$. lophyropoda at scales ranging from 0.5 to $2 \mathrm{~m}^{2}$ and its discontinuous geographic distribution may be partially explained by strong phylopatry of its larvae due to their poor swimming ability and limited dispersal. The dominance of $C$. crambe in littoral assemblages, its random distribution at scales larger than $0.5 \mathrm{~m}^{2}$, and its ubiquity along the littoral are traits that are consistent with high reproductive output, the swimming behaviour of larvae which facilitates wide dispersal, and patterns of recruitment found in this study. Therefore, S. lophyropoda populations appear to be maintained by offspring supplied by autochthonous individuals while populations of C. crambe appear to be open, with a potentially significant flow of larvae between them.
\end{abstract}

KEY WORDS: Reproductive output - Larval behaviour - Settlement Recruitment Spatial patterns Encrusting sponges Mediterranean Sea

\section{INTRODUCTION}

Our present understanding of the role of larval and post-larval processes in structuring marine benthic

-E-mail: iosune@ceab.csic.es communities is strongly influenced by the concept of a largely unpredictable supply of new recruits through the arrival of larvae and/or propagules ('supply-side ecology', e.g. Lewin 1986, Roughgarden et al. 1987 , Underwood \& Fairweather 1989). For most benthic invertebrates, the local production of offspring has lit- 
tle or no effect on local population size and structure (Caley et al. 1996). Some exceptions to this broadly accepted theory are to be found among clonal benthic organisms, which display a panoply of mechanisms accounting for limited dispersion of larvae (Jackson 1986. Grosberg 1987, Hurlbut 1992, Svane \& Havenhand 1993, Turon \& Vázquez 1996). These mechanisms and the role of resident populations in recruitment (e.g. Osman \& Whitlatch 1995) sometimes lead to autoregulation of local populations.

Irrespective of the allochthonous or autochthonous origin of the larval supply, settlement may be selective or random. Selective settlement in a suitable habitat may be advantageous as it may result in low mortality rates after settlement (Martín et al. 1992, Stoner 1994). Larvae may be induced to settle by phototaxis (e.g. Maida et al. 1994), surface topography (Carleton \& Sammarco 1987) or chemical cues (e.g. Burke 1986 , Pawlik 1992, Toonen \& Pawlik 1996). They may also approach suitable habitats as a result of their particular behaviour or hydrodynamic characteristics, such as shape, density, pattern of ciliation, and production of threads (Woollacott 1993, Abelson et al. 1994, Boettcher \& Targett 1996, Maldonado et al. 1997).

Selective settlement and limited dispersal of larvae often lead to aggregated spatial patterns (e.g. Carlon \& Olson 1993, Petersen \& Svane 1995, Turon \& Vázquez 1996j. Asexual reproduction may also contribute to aggregation in modular organisms. This reproductive strategy is particularly frequent in sponges without an organised skeleton [e.g. Oscarella lobularis (Schmidt), Chondrosia reniformis Nardo], in sponges with ropelike or branching shapes (Wulff 1985, 1991, 1995, Tsurumi \& Reiswig 1997) and in some thickly encrusting species inhabiting caves (Bibiloni et al. 1989). Aggregated distributions presumably resulting from sexual reproduction have been noted in hexactinellid sponges dwelling on bathyal bottoms (Martín et al. 1992) and in some caves (Boury-Esnault \& Vacelet 1994, Vacelet 1996). Aggregation patterns of littoral demosponges have been described only occasionally (Dayton 1979, Butler 1986), with no information on whether these patterns are the result of sexual or asexual processes (or both). Recruitment and settlement of several sponge species have been studied in the field using different methods (Reiswig 1973, Ayling 1980, Fell \& Lewandrowski 1981, Fell et al. 1984, Barthel 1986, Battershill \& Bergquist 1990, Pansini \& Pronzato 1990, Zea 1992). However, the relationship between patterns of recruitment and patterns of adult distribution has rarely been addressed in sponges (Butler 1986, Zea 1993. Meroz \& Ilan 1995, Maldonado \& Young 1996). More specifically, the possible influence of resident adults on larval recruitment has seldom been considered.
The species Crambe crambe (Schmidt) and Scopalina lophyropoda Schmidt are common encrusting sponges in the western Mediterranean sublittoral (Boury-Esnault 1971, Pulitzer-Finali 1983, Uriz et al. 1992 and references therein). Although they can coexist, these 2 species display contrasting geographic distributions: whereas C. crambe is widespread along the whole western Mediterranean, S. lophyropoda is concentrated in particular areas. Until the last decade, the latter species had only been recorded from 4 Mediterranean localities where, however, it was abundant (Schmidt 1862, Topsent 1934, Boury-Esnault 1971, Uriz 1982a). Conversely, C. crambe has been recorded in most descriptive surveys on Mediterranean littoral assemblages. Previous studies have shown that $C$. crambe produces toxic metabolites that inhibit settlement of bryozoan and echinoderm larvae in the laboratory (Martín \& Uriz 1992, Becerro et al. 1997). In contrast, $S$. lophyropoda was non-toxic in the same bioassays (authors unpubl.). We expected, therefore, that recruitment would be inhibited in the vicinity of $C$. crambe, while it would not be affected by the presence of S. lophyropoda.

During observation of sympatric populations of both species at a site in the northwestern Mediterranean (NE of Spain) over the past $10 \mathrm{yr}$, we detected an increasing abundance of Scopalina lophyropoda, which appeared to display an aggregated distribution. In contrast, the abundance of Crambe crambe remained more or less stable in the same period, with no apparent clumping in its distribution. The goal of this study was to assess whether reproductive output, larval behaviour, or recruitment patterns account for the spatial distribution of these 2 representative sponges and, if so, to examine possible mechanisms to explain the patterns

\section{MATERIALS AND METHODS}

Study area. The study area consists of several rocky walls facing north, at between 6 and $12 \mathrm{~m}$ depth, running parallel to the coastline on the Blanes littoral $\left(41^{\circ} 40.12^{\prime} \mathrm{N}, 2^{\circ} 47.10^{\prime} \mathrm{E}\right.$, western Mediterranean). These walls harbour homogeneous semi-sciaphilous assemblages (see Becerro et al. 1994 for a detailed description of the communities). The encrusting sponges Crambe crambe and Scopalina lophyropoda are the dominant invertebrates in terms of surface cover (Turon et al. 1996). These species share habitat, although the range of vertical distribution of $C$. crambe is somewhat wider than that of $S$. lophyropoda.

Abundance, cover and pattern. Sponge cover was estimated by randomly placing $625 \mathrm{~cm}^{2}$ quadrats $(\mathrm{n}=$ 200 ) on the walls. These quadrats were subdivided into 
25 subquadrats of $25 \mathrm{~cm}^{2}$ each (Ballesteros 1996). We recorded the number of subquadrats in which either of the 2 sponge species was present $(S)$ and calculated the percentage cover for each sponge $(C)$ as follows:

$$
C=\left(S \times 25 \mathrm{~cm}^{2} / 625 \mathrm{~cm}^{2}\right) \times 100
$$

Differences in percentage cover were analysed by a Mann-Whitney $U$-test as data were not normally distributed even after trying several transformations (Zar 1984).

As for the analysis of spatial patterns, we used the belt method, which has shown its applicability for the detection of pattern at increasing scales by pooling adjacent areas (Krebs 1989. Underwood \& Chapman 1996).

We placed four $10 \mathrm{~m}$ horizontal line transects at random on vertical walls, and recorded all the specimens of each species present half a meter above or below the line in each $1 \mathrm{~m}$ segment of the transect. In this way, we obtained records for adjacent $0.5 \times 1 \mathrm{~m}$ quadrats We tested aggregation at this scale by computing the Morisita dispersion index (Morisita 1959, Elliot 1977 , Bakus 1990), which is independent of the sample mean and of the total number of individuals. This index equals 1 for a random distribution, is greater than 1 for a contagious distribution, and is less than 1 for a regular distribution. Its significance can be tested against a chi-square distribution (Elliot 1977, Krebs 1989). In our case, the contiguous quadrats did not provide an independent estimate of abundance. Therefore, we resampled within transects by taking quadrats at random up to one-third the transect size. In this way, the samples were approximately independent and the significance of the Morisita index obtained could be tested.

To analyse pattern at increasing scales, the initial quadrats $\left(0.5 \mathrm{~m}^{2}\right)$ were subsequently grouped along the transect in sets of 4 adjacent quadrats (Mead 1974). We then computed the absolute difference between the first and second pair of quadrats within each set of 4 , and summed all these differences in order to obtain a measure of the variations between adjacent pairs. We can then compare this observed statistic with the distribution obtained through random pairings of the quadrats within the groups of 4 , i.e. without constraining the pairs to be formed by adjacent readings. As there are 3 possible ways of grouping 4 quadrats into 2 pairs, there are 3 possible absolute differences between pairs, and the randomisation distribution has $3^{n}$ values ( $n=$ number of sets of 4 that can be constructed). If the proportion of the randomised distribution that is greater than the observed sum of differences is less than 0.05, we can judge that there is a significant aggregation at the scale of the size of the pairs. We used the parametric-free version of this test (for details see Mead 1974). This method allows testing for aggregation at scales of size successively doubled until half the length of the transect is reached (i.e. at scales of $1 \mathrm{~m}^{2}, 2 \mathrm{~m}^{2}$ and $4 \mathrm{~m}^{2}$ in our case).

Reproductive output. The potential number of larvae for release during the whole reproductive period in the area studied was estimated by counting the number of embryos incubated per unit area of sponge under a stereomicroscope. Counts were done on randomly collected specimens ( $n=50)$ of each species prior to any larval release. One circular piece $\left(3 \mathrm{~cm}^{2}\right)$, chosen at random, was cut off from each specimen and dissected. The larvae released in the laboratory, and the immature embryos, were counted. The resulting figures may overestimate the actual number of larvae expelled since some embryos may never be released from the sponge and are resorbed (Bergquist \& Sinclair 1968, Maldonado \& Young 1996). We assumed that the proportion of embryos resorbed is similar in both species and used the values obtained for comparative purposes. The reproductive output ( $\mathrm{RO}$ ) was calculated as the product of the number of embryos plus larvae per unit area of sponge $(E L)$ and the species' mean coverage (MC):

$$
\mathrm{RO}=\mathrm{EL} \times \mathrm{MC}
$$

By comparing the potential number of larvae available in the water column with the number of recruits obtained in field quadrats (see below), we estimated the contribution of the larval production to the maintenance of the local populations. Differences in numbers of larvae plus developing embryos per unit area between sponge species were tested by the non-parametric Mann-Whitney $U$-test, as the data were not normally distributed.

Larval shape, size, and behaviour. Ripe sponges of both species were collected and transported to the laboratory in plastic containers. Larval release in the containers was either spontaneous or triggered by shaking the sponges. Upon release, larvae were collected with a pipette and placed in $500 \mathrm{ml}$ glass containers with filtered sea water $(0.45 \mu \mathrm{m}$ pore $)$.

Larval shape was recorded through a stereomicroscope. Larval sizes ( $\mathrm{n}=55$ for both species) were derived, immediately after fixation in $4 \%$ formaldehyde, by projecting the image magnified through a Wild M-10 stereomicroscope and a camera lucida onto a 'Genius' digitizer pad using the HiPa2 software (by K. Foreman, Woods Hole Oceanographic Institution). Major (length) and minor (width) axes were recorded for each larva and an index of larval shape $(I)$ was calculated as follows:

$$
I=1-\frac{\text { width }}{\text { length }}
$$

The index of larval shape was compared between species by using the Mann-Whitney $U$-test. 
Swimming behaviour was examined mainly in laboratory experiments, although occasional observations on larval release and behaviour were recorded in the field. In a few cases, larvae were followed at some distance ( 1 to $2 \mathrm{~m}$ ) by divers. Distances from the parental sponge reached by the larvae 15 min after release were recorded, although the scarcity of these observations prevented statistical analysis of these data.

Experiments were conducted in the laboratory at 23 to $24^{\circ} \mathrm{C}$ (similar to the sea temperature) under dim, diffuse light. In the first experiment, we placed 20 recently released larvae (less than $6 \mathrm{~h}$ old) of each species in cylindrical containers $(9 \mathrm{~cm}$ in diameter, $6 \mathrm{~cm}$ in height) (15 replicates for each species) with filtered sea water $(0.45 \mu \mathrm{m}$ pore), totalling 300 larvae per species. The water in the containers with the larvae was shaken vigourously for a few seconds. We recorded the position of the larvae in the containers 5 and 10 min after shaking. The variables quantified were posture of the larvae (either vertical or horizontal/inclined) and behaviour of the larvae (either swimming in the water column or crawling on the bottom or walls of the container). After the experiment, larvae were maintained in the containers to monitor settlement preferences (\% of larvae settled on the bottom, walls, and on the water surface) for each species.

We found a relatively high number of larvae of $\mathrm{Sco}$ palina lophyropoda entrapped at the water surface of the experimental containers. In the field, these larvae stay close to conspecifics and rarely reach the sea surface. Thus, we performed a second experiment trying to avoid the possible artefact due to the short water column $(6 \mathrm{~cm})$ of the containers used in the first experiment. For this second experiment, we used $27.3 \mathrm{~cm}$ high, $9 \mathrm{~cm}$ diameter calibrated cylindrical containers and carefully placed one 6 h old larva of each species on the bottom with a long pipette. We performed 100 replicates for each species and recorded the distance of each larva from the bottom 5 min after being released. The purpose of this experiment was to determine whether, under static conditions, larvae of $S$. lophyropoda stay close to their initial position after release (as observed in the field), even in the absence of conspecifics.

Data from the first experiment on larval behaviour were analysed with a multivariate repeated measures design (MANOVAR, Von Ende 1993), with species as the between-subject factor ( 2 levels) and time (2 levels) as the within-subject factor. The number of replicates $(n=15)$, the levels of the between-subject factor $(M=2)$ and the number of dependent variables $(k=2)$ in this multivariate design guaranteed its power since it complied with the constraint $n-M>k+9$, as recommended by Maxwell \& Delaney (1990). The percentages of larvae swimming after 5 and $10 \mathrm{~min}$ (SW5 and SW10, respectively) were log-transformed to meet the assumptions of the MANOVAR (Box M test). No data transformation was necessary for the percentages of larvae in a vertical posture after 5 and $10 \mathrm{~min}$ (V5 and $\mathrm{V} 10$, respectively).

Data from the second experiment (distance from the bottom $5 \mathrm{~min}$ after release) did not meet the assumptions of parametric tests even after several transformations. They were analysed by the Mann-Whitney $U$-test (Zar 1984).

Preferences at settlement in the containers were analysed by a 2-way ANOVA with species (2 levels) and location in the bowl (3 levels) as factors. Data met the assumptions of this parametric procedure

Recruitment. We designed an experiment in order to quantify recruitment rates of each species and the possible effect of the presence of adult specimens of either of these species on conspecific larvae and on larvae of the other species.

Before the season of larval release, areas of $310 \mathrm{~cm}^{2}$ were scraped to reveal rock in the central zone of large $\left(>2500 \mathrm{~cm}^{2}\right.$ ) specimens of Scopalina lophyropoda and Crambe crambe ( $\mathrm{n}=10$ for each species). These areas will hereafter be called S. lophyropoda quadrats and C. crambe quadrats, respectively. The scraped areas were carefully cleaned of possible sponge remnants with an iron brush. Brushing was repeated after $1 \mathrm{wk}$ to eliminate previously unseen remnants that had begun to regenerate. The same procedure was applied to 10 areas in neighbouring vertical rocky zones that were free from sponges and mainly covered with a seaweed turf (hereafter called control quadrats). The sponge individuals and the control rocky areas were chosen at random in the assemblages established on several northward-facing walls.

The timing of larval release in Scopalina lophyropoda and Crambe crambe overlapped from the end of July until the end of August. The scraped quadrats were photographed to monitor recruits of both species during the whole release period. We define as recruit a juvenile censused in any given observation interval. Obviously, recruitment was the result of settlement and mortality processes. Pictures were taken weekly with a Nikonos camera and a $35 \mathrm{~mm}$ objective plus a close-up lens. Recruits of $S$. lophyropoda were distinguishable from those of $C$. crambe on the slides because of their yellow to pale orange colour in contrast to the bright orange to red colour of $C$. crambe's recruits

Our data on recruitment did not meet the assumptions about the variance-covariance matrix necessary for a repeated measures analysis (Potvin et al. 1990, Von Ende 1993), even after trying several transformations. So, the number of recruits recorded for each scraped quadrat in each of the 4 weeks of observation 
was compared among treatments (quadrats in Crambe crambe, Scopalina lophyropoda and controls) by a parametric-free randomisation version of a repeated measures analysis of variance based on Manly (1991). This method consisted of a 2 -stage permutation of the data: first, quadrats were randomly reassigned to the 3 treatments, and then readings for each quadrat were randomly rearranged among observation times. With this 2-level randomisation, the overall total sum of squares, as well as the total between-and within-subject sums of squares, remains unchanged (Manly 1991). The sum of squares associated with each factor and their interaction is, therefore, a suitable statistic on which to test the significance of each effect. We approximated the distribution of the sum of squares for each factor and their interaction under the null hypothesis by using 9999 randomisations of the data set plus the observed data order. We judged an effect to be significant when the observed sum of squares was exceeded by less than $5 \%$ of the corresponding values in the randomisation series. Post-hoc pairwise comparisons were performed with Bonferroni's correction.

All the analyses were performed with the packages Systat $v 5.0$ and Statistica $v 4.0$. The randomisation programs were written in Turbo Pascal.

\section{RESULTS}

\section{Abundance, cover, and pattern}

The species Crambe crambe was much more abundant than Scopalina lophyropoda in the area studied, both with respect to the number of individuals per $\mathrm{m}^{2}$ $(67 \pm 2.7$ vs $10.2 \pm 2.1$, mean $\pm \mathrm{SE})$ and the cover $(47 \pm$ 1.9 vs $11.1 \pm 1.4 \%)$. The differences were significant for both variables ( $p<0.001$, Mann-Whitney $U$-test). At the smallest scale sampled $\left(0.5 \mathrm{~m}^{2}\right)$, the dispersion index of Morisita was 1.099 for C. crambe and 3.67 for $S$. lophyropoda. Both are, however, significant (chisquare test, $p<0.05$ ), indicating aggregation at this scale, although the strength of this aggregation was notably higher in S. lophyropoda. This species also had an aggregated distribution at the scale of $1 \mathrm{~m}^{2}(\mathrm{p}=$ 0.039 ) and $2 \mathrm{~m}^{2}(\mathrm{p}=0.004)$, but not at $4 \mathrm{~m}^{2}(\mathrm{p}=0.385)$. No larger scale could be tested, as our transects were $10 \mathrm{~m}$ long. In contrast, $C$. crambe did not show a significant aggregation at any scale higher than $0.5 \mathrm{~m}^{2}$ (all $\mathrm{p}>0.22$ ).

\section{Reproductive output}

The density of embryos was about 5 times higher in Crambe crambe than in Scopalina lophyropoda $176.2 \pm$
12.5 vs $14 \pm 1.7$ embryos $\mathrm{cm}^{-2}$, mean $\pm \mathrm{SE}$ ), the differences between species being significant $(p<0.01$, Mann-Whitney U-test). There was a much higher variability in C. crambe than in S. lophyropoda. An appreciable number of specimens $(8.5 \%)$ in C. crambe did not brood any embryos (contrasting with only $4.5 \%$ non-brooding specimens in S. lophyropoda). Furthermore, some $C$. crambe individuals featured an extremely high density of embryos (more than $200 \mathrm{~cm}^{-2}$ ), while none of the examined specimens of $S$. lophyropoda brooded more than about 50 embryos $\mathrm{cm}^{-2}$.

\section{Larval shape, size, and behaviour}

The larvae of these 2 species differed in shape. In both cases, the shape matched the general characteristics described for the larvae of their respective taxonomic orders, Poecilosclerida (Crambe crambe) and Halichondrida (Scopalina lophyropoda) (Bergquist \& Sinclair 1968). Larvae of $C$. crambe were ovoid or sausage-shaped and, occasionally, spherical. They were $844.2 \pm 31.5 \mu \mathrm{m}$ long and $457 \pm 9.6 \mu \mathrm{m}$ wide (mean $\pm \mathrm{SE}$ ). Length and width were negatively correlated $(r=0.7, p<0.001)$. The larval shape index $I$ ranged from 0 to $0.75(0.43 \pm 0.03$, mean $\pm \mathrm{SE})$. The larvae are evenly ciliated except at the posterior pole, where they have a bare rounded area covered by flat cells (Becerro 1994).

In contrast, larvae of Scopalina lophyropoda were clearly elongated with a rounded anterior pole and a narrower pointed posterior pole. They measured $1481.8 \pm 26.4 \mu \mathrm{m}$ in length, $467.8 \pm 9.8 \mu \mathrm{m}$ in width (mean \pm SE) and were evenly ciliated. Length and width were not correlated ( $r=0.2, p=0.09$ ). The shape index in this species ranged from 0.56 to $0.79(0.68 \pm$ 0.007 , mean $\pm \mathrm{SE}$ ). Larvae of $S$. lophyropoda were significantly more elongated than those of Crambe crambe (shape index $\mathrm{p}<0.001$, Mann-Whitney U-test).

Although larvae of both species swam more actively when they received some light, no particular phototaxis was observed during the first hours of free-swimming life in preliminary experiments. In both cases, larvae became photonegative at settlement.

Larvae of the 2 species behaved in a contrasting way when release was observed in the field. Upon release, larvae of Scopalina lophyropoda remained close to parental sponges (from 2 to $10 \mathrm{~cm}$ above them) and stayed in a vertical posture with the wider (anterior) pole towards the sea surface and the pointed (posterior) pole towards the sea bottom. They maintained their original position during the observation (15 min) by rotating around their longitudinal axis, minimising horizontal movement. This particular behaviour resulted in a high concentration of larvae close to their 


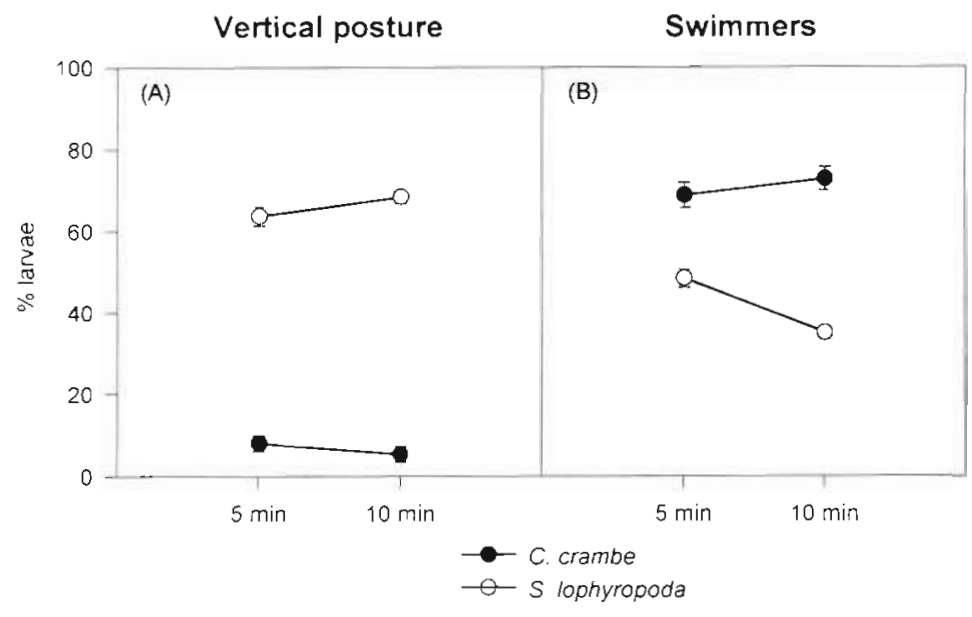

Fig. 1. Crambe crambe and Scopalina lophyropoda. Results (obtained in the laboratory) on posture and activity of larvae of both species 5 and 10 min after the water in the containers was shaken. (A) Percentage of larvae in a vertical posture. (B) Percentage of swimmers. Bars indicate standard errors

conspecifics and in their absence from the water column. In contrast, larvae of Crambe crambe swam with a corkscrew motion in a wavy, irregular way and were dispersed several meters away from the parental sponge immediately after release. They were abundant in the whole water column, even far from the rocky walls.

This behaviour in the field was consistent with the results from our laboratory experiments. In the first experiment, the percentages of larvae of Crambe crambe in a vertical posture were $8 \pm 2$ and $5.3 \pm 2 \%$ (mean $\pm \mathrm{SE}$ ) after 5 and $10 \mathrm{~min}$, respectively, while the corresponding values for Scopalina lophyropoda larvae were $63 \pm 2.4$ and $68.3 \pm 1.6 \%$ (Fig. 1A). The multivariate repeated measures analysis on larval body posture (V5 and V10) indicated that the species factor was significant $(p<0.001)$ and time was not $(p=0.56)$, but there was a significant interaction term as well ( $p<$ 0.05) (Table 1). The significant interaction term indi-

Table 1. Crambe crambe and Scopalina lophyropoda. MANOVAR on \% of larvae with a vertical. posture 5 and $10 \mathrm{~min}$ after the water in the experimental containers was shaken

\begin{tabular}{lrrrc|}
\hline Source & $\mathrm{df}$ & MS & $F$ & $\mathrm{p}$ \\
\hline Between subjects & & & & \\
$\quad$ Species & 1 & 52806.660 & 700.198 & $<0.001$ \\
$\quad$ Error & 28 & 75.416 & & \\
$\quad$ Within subject & & & & \\
$\quad$ Time & 1 & 15.000 & 0.347 & 0.560 \\
$\quad$ Species $\times$ Time & 1 & 201.670 & 4.673 & 0.039 \\
$\quad$ Error & 28 & 43.154 & & \\
\hline
\end{tabular}

cated a different percentage of larvae in a vertical posture over time for each species, i.e. decreasing in C. crambe and increasing in $S$. lophyropoda (Fig. 1A). With respect to the $\%$ of swimming larvae (SW), this variable showed significant species $(p<0.001)$ and time $(p<0.01)$ effects, although it also varied differently in both species with time (interaction term, $\mathrm{p}<0.001$ ) (Table 2). In the presence of a significant interaction term, no conclusion could be drawn for the main factors separately (Underwood 1981), and we performed separate $t$-tests at each time point. Significantly more larvae of $S$. lophyropoda $(p<0.001)$ stayed in a vertical posture than those of $C$. crambe after both 5 and $10 \mathrm{~min}$. Similarly, the \% of swimmers was significantly higher $(p<0.001)$ in larvae of $C$. crambe than in those of S. lophyropoda after both 5 and $10 \mathrm{~min}(68.7 \pm 3$ and $72.7 \pm 2.8 \%$, mean $\pm \mathrm{SE}$, in C. crambe; $48.3 \pm 2.2$ and $35 \pm$ $1.5 \%$ in S. lophyropoda Fig. 1B). In short, $S$. lophyropoda larvae adopted a vertical posture much more often than $C$. crambe larvae both in the water column and on the container walls (Fig. 1A). The former rotated around their longitudinal axis and soon began to crawl (52 and $65 \%$ were crawling after 5 and $10 \mathrm{~min}$, respectively). Conversely, C. crambe larvae were active swimmers and showed little tendency to crawl (only $30 \%$ were crawling after both 5 and $10 \mathrm{~min})$. They repeatedly reached and left the container walls and bottom and were found predominantly in the water column during observation

In the second experiment, when larvae were placed on the bottom of the $27.3 \mathrm{~cm}$ high containers, larval behaviour was significantly different for the 2 species. Larvae of Scopalina lophyropoda were significantly closer to the bottom than those of Crambe crambe ( $\mathrm{p}<$ 0.001 , Mann-Whitney $U$-test) $5 \mathrm{~min}$ after release. The former did not reach the water surface except in the rare cases in which they contacted the container walls

Table 2. Crambe crambe and Scopalina lophyropoda. MANOVAR on \% of larvae (log-transformed) swimming 5 and 10 min after the water in the experimental containers was shaken

\begin{tabular}{|rrrrr|}
\hline Source & df & MS & $F$ & $p$ \\
\hline $\begin{array}{l}\text { Between subjects } \\
\quad \text { Species }\end{array}$ & 1 & 0.832 & 700.198 & $<0.001$ \\
$\quad$ Error & 28 & 0.006 & & \\
$\quad$ Within subject & & & & \\
$\quad$ Time & 1 & 0.048 & 11.677 & 0.002 \\
$\quad$ Species $\times$ Time & 1 & 0.104 & 24.967 & $<0.001$ \\
Error & 28 & 0.004 & & \\
\hline
\end{tabular}




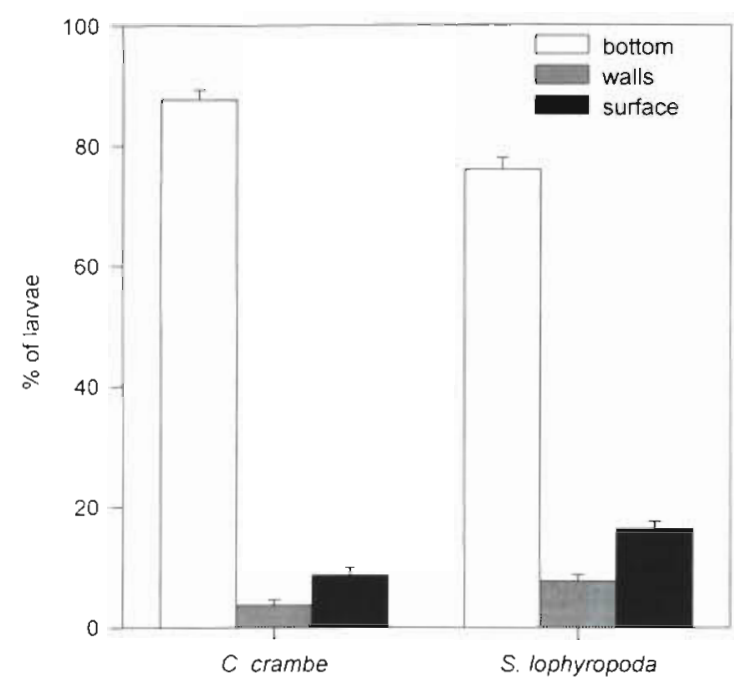

Fig. 2. Crambe crambe and Scopalina lophyropoda. Percentage of larvae of both species that settled on the bottom, walls, and water surface of the experimental containers. Bars indicate standard errors

and crept upwards. In general, larvae of this species stayed in a vertical posture at a mean distance of $2.8 \pm$ $0.6 \mathrm{~cm}$ (mean $\pm \mathrm{SE}$ ) from the bottom. Just after release, some rose to $10-15 \mathrm{~cm}$ from the bottom, but after a few seconds they went down again. Conversely, larvae of C. crambe rose immediately after being released. The mean distance from the bottom after 5 min was $19.4 \pm$ $0.9 \mathrm{~cm}$. Additional observations showed that $S$. lophyropoda larvae maintained their position close to the bottom for at least 20 min (we did not continue monitoring any longer), whereas most larvae of $C$. crambe were close to the water surface after $20 \mathrm{~min}$.

Larvae of both species maintained in the experimental containers ( $n=15$ for each species, 20 larvae in each container) had a 24 to $72 \mathrm{~h}$ free-living stage. We recorded the numbers that settled on the 3 types of surface available: bottom and walls of the containers, and water surface. Larvae of both species settled preferentially on the container bottom $187.8 \pm 1.3$ and $76 \pm$ $1.8 \%$, mean $\pm \mathrm{SE}$, for Crambe crambe and Scopalina lophyropoda, respectively) and less often on the walls

Table 3. Crambe crambe and Scopalina lophyropoda. Twoway ANOVA for species and settlement site (bottom and walls of the containers, and water surface) effects on percentage of settlers

\begin{tabular}{|lrrrrc|}
\hline Source & SS & df & MS & $F$ & p \\
\hline Species & $<0.001$ & 1 & $<0.001$ & 0.000 & 0.99 \\
Site & 106551.700 & 2 & 53275.830 & 1814.258 & $<0.001$ \\
Species $\times$ Site & 1581.667 & 2 & 790.830 & 26.931 & $<0.001$ \\
Error & 2466.667 & 84 & 29.365 & & \\
\hline
\end{tabular}

Table 4. Crambe crambe and Scopalina lophyropoda. Oneway ANOVAs on settlement preferences for each species (bottom and walls of the containers, and water surface) in the laboratory experiment

\begin{tabular}{|lrrrrr|}
\hline Source & SS & df & MS & F & p \\
\hline C. crambe & & & & & \\
Site & 66610.000 & 2 & 33305.000 & 1345.010 & $<0.001$ \\
Error & 1040.000 & 42 & 24.760 & & \\
S. lophyropoda & & & & & \\
Site & 41523.330 & 2 & 20761.670 & 611.207 & $<0.001$ \\
Error & 1426.670 & 42 & 1.358 & & \\
\hline
\end{tabular}

$(3.7 \pm 0.5$ and $9 \pm 0.9 \%)$ or on the water surface $(8.5 \pm$ 1.1 and $15 \pm 0.9 \%$ ) (Fig. 2). A 2 -way ANOVA with species and type of surface as factors indicated that the species factor was not significant $(p=0.99)$. However, the type of surface was highly significant ( $p<0.001$ ) as was the interaction term $(p<0.001)$ (Table 3$)$. Separate 1 -way ANOVAs on the type of surface for each species showed a significant effect in both cases $(p<0.001)$ (Table 4). Pairwise comparisons (Tukey test) showed that larvae settled significantly more frequently on the container bottom than on the walls or the water surface layer ( $p<0.001$ for both species), and that settlement was significantly higher on the water surface than on the walls $(p<0.05$ and $p<0.001$ for $C$ crambe and $S$. lophyropoda, respectively).

\section{Recruitment}

The number of recruits per quadrat (all substrates pooled) at the end of the period of larval release was $15.6 \pm 1.97$ and $5.12 \pm 1.16$ (mean $\pm \mathrm{SE}$ ) for Crambe crambe and Scopalina lophyropoda, respectively. The density of recruits of each species for each substrate and observation time is depicted in Fig. 3.

In the case of Crambe crambe (Fig. 3A), recruitment increased progressively in control and $C$. crambe quadrats with time, but it did not in substrates surrounded by Scopalina lophyropoda. This difference in recruitment was confirmed by a significant $(p<0.01)$ interaction between substrate and time in the randomisation repeated measures analysis. We then repeated the randomisation analysis leaving out the S. lophyropoda quadrats, and found that the number of recruits was significantly higher in C. crambe than in control quadrats (substrate effect, $p=0.029$ ). The analysis also revealed that the number of recruits varied significantly between observation times (time effect, $\mathrm{p}<$ 0.001), and that $C$. crambe and control quadrats showed the same trend over time (interaction term, $\mathrm{p}=$ 0.939 ). 


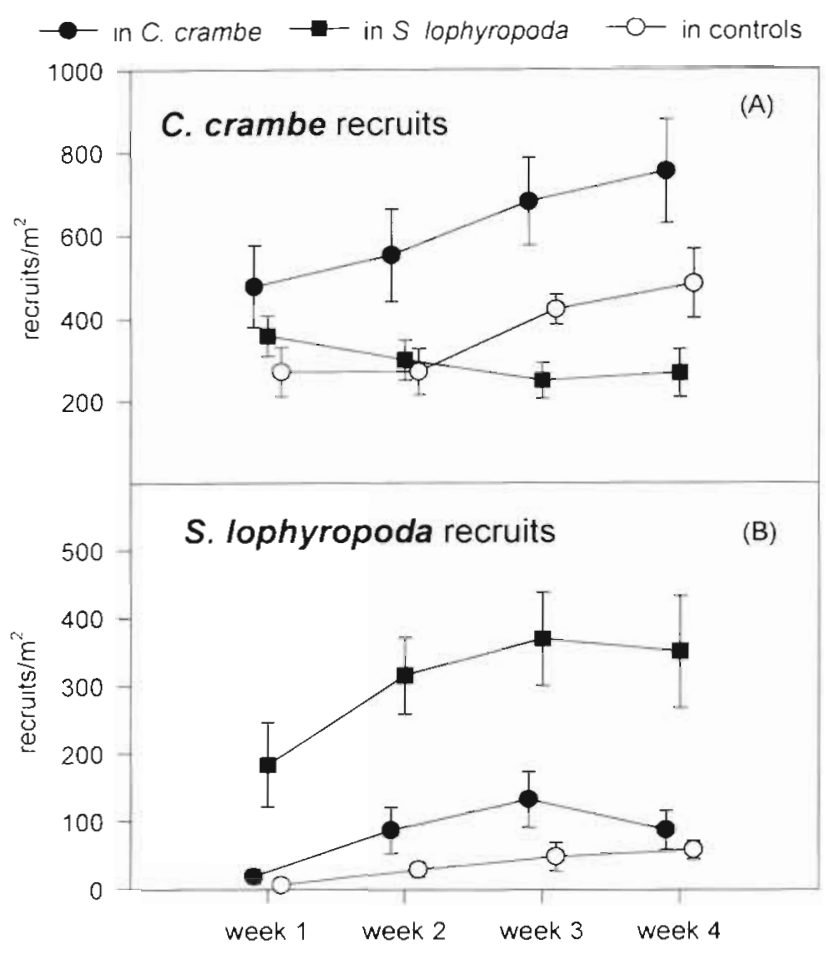

Fig. 3. Number of recruits per $\mathrm{m}^{2}$ on scraped quadrats surrounded by the different types of organism. (A) Recruits of Crambe crambe. (B) Recruits of Scopalina Lophyropoda. Bars indicate standard errors

For Scopalina lophyropoda, there were significantly more recruits in quadrats surrounded by conspecifics than in control or Crambe crambe quadrats (Fig. 3B). The repeated measures analysis showed a significant substrate effect ( $p<0.001$ ), and pairwise comparisons between substrates (with Bonferroni correction) showed that this effect was due to the higher number of recruits in $S$. lophyropoda quadrats than in $C$. crambe or in control quadrats. The number of recruits also varied among observation times (repeated measures analysis, $p<0.001$ ), while the interaction between time and substrate was not significant ( $p=$ 0.384 ), indicating a parallel trend with time in the 3 substrata.

\section{DISCUSSION}

The number of larvae per unit area produced by Crambe crambe was significantly higher (about 5 times) than that produced by Scopalina lophyropoda. Furthermore, the percentage of substrate covered at the study site was also higher (about 4 times) for the former species. This results in a potential number of larvae of $C$. crambe in the water column of about 20 times higher than that of $S$. lophyropoda. In contrast, the mean number of recruits found per unit area after 1 mo was only ca 3.5 times higher in C. crambe than in $S$. lophyropoda (all substrata pooled). This indicates that fecundity is not a good predictor of local recruitment for $C$. crambe, since a significant proportion of $C$. crambe's larval production does not contribute to the local population. Mortality at the larval and early postlarval stages may be considerably higher in C. crambe. Predation on $C$. crambe larvae and settlers by small fish has been documented (Uriz et al. 1996a) and we have observed some instances of larvae being captured by the cnidarian Eudendrium ramosum L. No cases of predation on $S$. lophyropoda larvae or settlers have been recorded, which suggests a higher predation pressure on the former species.

In the field, the mean number of Scopalina lophyropoda recruits at the last observation time was about 7 times higher in S. lophyropoda quadrats than in controls ( 350 vs $58 \mathrm{~m}^{-2}$ ). On the other hand, the mean number of Crambe crambe recruits was less than double in C. crambe quadrats than in controls (753 vs $483 \mathrm{~m}^{-2}$ ) at the end of the monitoring. This indicated a significant tendency of both species to settle within spaces surrounded by conspecifics, although this tendency is weaker in $C$. crambe. Contrary to what we expected, the toxicity of $C$. crambe was not reflected by an inhibition of settlement of the other species, as no differences in $S$. lophyropoda recruitment were found between control and $C$. crambe quadrats. Although toxicity has been located in cells of $C$. crambe that are extruded through the sponge surfaces (Uriz et al. 1996b), there is no definite evidence on how far from the sponge these toxic molecules can be effective in the field. Bingham \& Young (1991) also report a lack of effect of toxic sponges on settlement in the field.

The behaviour of larvae in the laboratory was consistent with observations in the field. Larvae of Scopalina lophyropoda did not swim away from the release point; they preferentially maintained a vertical posture and soon began to crawl. In contrast, larvae of Crambe crambe were active swimmers, showing a tendency to swim towards the water surface throughout the experiments. Overall, these results were consistent with the fact that $S$ lophyropoda recruited substantially more than $C$. crambe within conspecifics. Therefore, larval behaviour alone would explain the recruitment patterns observed under natural conditions.

Although larvae of both species settled preferentially on horizontal surfaces in the laboratory experiments, adult specimens were much more frequent on vertical surfaces at the study site. This is probably due to the instability of the horizontal surfaces available there $(10$ to $15 \mathrm{~m}$ deep, detritic bottom perturbed by 
waves and littoral currents), which prevents settlement. However, both species have often been recorded on horizontal rocky surfaces in more appropriate habitats (Boury-Esnault 1971, Bibiloni 1990, authors unpubl.). The settlement on the water surface found in a relatively high percentage of larvae in our experiments is commonly found in laboratory experiments (e.g. Fry 1971, Uriz 1982b, Kaye 1990). It should be considered as an artefact due to the static experimental conditions as it does not occur when the water is agitated continuously (Fry 1971).

A weak but significant aggregation was found for the population of Crambe crambe at a scale of $0.5 \mathrm{~m}^{2}$ although its distribution was random at larger scales (i.e. 1, 2, and $4 \mathrm{~m}^{2}$ ). This aggregation at the smallest scale may be the result of enhanced settlement close to conspecifics (as found in our recruitment experiment), although fragmentation, documented for this species (Turon et al. in press), may also contribute to the pattern found. In contrast, aggregation in Scopalina lophyropoda was strong at the scales of 0.5, 1 and $2 \mathrm{~m}^{2}$. Although fragmentation may also contribute to this contagious distribution at the smaller scales, it seems unlikely to explain aggregation over such a range of scales. An aggregated spatial pattern in benthic invertebrates may result from gregarious settlement, selection of microhabitats or limited dispersal (Carlon \& Olson 1993). According to our observations, limited dispersai due to swimming behaviour and early crawling is the most likely cause in S. lophyropoda. This does not preclude chemical cues in this species which may induce settlement close to conspecifics as in other benthic invertebrates (Bonar et al. 1990, Davis \& Moreno 1995). However, no chemical receptors allowing detection of chemical cues are known in parenchymella larvae.

Strathmann (1974), among others, discusses the advantages and disadvantages of phylopatric dispersal of larvae. Aggregation patterns facilitate fertilisation by proximity (e.g. Levitan 1991), and larvae that settle near adults benefit from a favourable habitat (Pawlik 1992). The resulting spatial pattern, however, makes the whole population more vulnerable to adverse events resulting in local extinction (Keough \& Chernoff 1987, Davis \& Butler 1989). Local extinction may also contribute to a patchy distribution at scales larger than those examined here. Thus, the processes ending in an aggregation pattern might act in a self-perpetuating way. The wider dispersal of Crambe crambe may result in advantages at the evolutionary scale (Strathmann 1974) by favouring species survival as a result of decreased susceptibility to local extinction and increased adaptation to a wider range of environments.

Under laboratory conditions, there were no differences in larval lifespan between the 2 species. Larvae settled between 24 and 72 h after being released, depending on the developmental stage but not on the species. Thus, a longer duration of the swimming period is not responsible for the wider dispersion and less aggregated pattern of Crambe crambe. In this study, the wider dispersion of C. crambe in the sea may be caused by the swimming behaviour of its larvae, which carries them away into the water column where they are more susceptible to being transported by currents and waves. Sponge larvae are weak swimmers (Maldonado \& Young 1996). Consequently, currents largely influence the rate and direction of horizontal transport. Scopalina lophyropoda seems to avoid this horizontal transport by spending most of the time close to the substrate where larval movements are determined more by their own abilities (Stoner 1994). The larval behaviour of $S$. lophyropoda approaches that described for halichondrid larvae (Bergquist \& Sinclair 1968) in that, despite swimming continuously, they move only short distances. However, this behaviour has also been described for larvae of the poecilosclerid Mycale microacanthoxea Buizer \& van Soest (Wapstra \& Soest 1987).

Crambe crambe is much more abundant than Scopalina lophyropoda along the western Mediterranean sublittoral. However, once $S$. lophyropoda has colonised a suitable substrate it seems able to proliferate even in the presence of C. crambe. After recruitment. faster growth and regeneration abilities (Uriz 1982a, authors' current research) may account for the observed increasing abundance of $S$. lophyropoda in the area of study during the last $10 \mathrm{yr}$.

One interesting conclusion is that these species display contrasting strategies in the larval and benthic stages, in contrast to other sponges which have the same strategy throughout their life history (Meroz \& Ilan 1995). With respect to larval production, larval behaviour, settlement pattern, and adult distribution, Scopalina lophyropoda behaved as a specialist whereas Crambe crambe was a clear opportunist. However, adults of C. crambe feature low growth and regeneration rates, and high investment in chemical and physical defences (Uriz et al. 1995, Turon et al. in press), while the opposite is found in S. lophyropoda (authors' current research). This mixing of life-strategies would explain the long-term increasing abundance in restricted areas of a fast-growing organism due to strong phylopatry of its larvae. Concepts of $r$ and $k$-selected species seem to break down in encrusting sponges as in other modular organisms when the whole life cycle is considered. Larval and post-larval stages should be coupled if we are to obtain a complete picture of the population dynamics of a species (Eckman 1996). To our knowledge, this combination of strategies in different developmental stages has been 
poorly documented, and its possible implications for life-history evolution remain unexplored.

In summary, larvae of Scopalina lophrropoda tended to remain in the same place for the whole larval period, settled preferentially close to conspecifics, and the adult populations showed an aggregated pattern over scales from 0.5 to $2 \mathrm{~m}^{2}$ and a patchy geographic distribution. S. lophyropoda populations seem to be under local control through restricted dispersal of larvae, the autochthonous specimens providing new recruits. Conversely, Crambe crambe larvae showed a tendency to swim away, recruitment close to conspecifics was enhanced to a lesser degree, and adult aggregation was much weaker compared to $S$. lophyropoda, while the species' geographic distribution was continuous throughout the western Mediterranean. $C$. crambe populations are, therefore, more open, and the larval supply contributing to a local population may come in part from neighbouring zones. The short larval life in this species, however, suggests that the scale at which we can consider these populations as open is far more restricted than that for species with planktotrophic, long-lived larvae.

Acknowledgements. We thank Eva Bravo, Carmen Carmona, and Maria Bardají for help in field and laboratory work. This research was funded by projects DGCYT PB94-0015 and CICYT MAR95-1764 of the Spanish Government and 1997 SGR 00084 of the 'Generalitat de Catalunya'

\section{LITERATURE CITED}

Abelson A, Welhs D, Loya Y. (1994) Hydrodynamic impediments to settlement of marine propagules, and adhesivefilament solutions. Limnol Oceanogr 39(1):164-169

Ayling A. (1980) Patterns of sexuality, asexual reproduction and recruitment in some subtidal marine Demospongiae. Biol Bull 158:271-282

Bakus GJ (1990) Quantitative ecology and marine biology AA Balkema, Rotterdam

Ballesteros E (1996) Un método rápido y efectivo para la elaboración de inventarios en el bentos rocoso. Algas 16:8-9

Barthel D 1986 On the ecophysiology of the sponge Halichondria panicea in Kiel Bight. I. Substrate specificity, growth and reproduction. Mar Ecol Prog Ser 32:291-298

Battershill CN, Bergquist PR (1990) The influence of storms on asexual reproduction, recruitment, and survivorship of sponges. In: Rützler $\mathrm{K}$ (ed) New perspectives in sponge biology. Smithsonian Institution Press, Washington, DC, p $397-403$

Becerro $M$ (1994) Chemically mediated bioactivity of the encrusting sponge Crambe crambe and its ecological implications. PhD thesis, Universitat de Barcelona

Becerro MA, Turon X, Uriz MJ (1997) Multiple functions for secondary metabolites in encrusting marine invertebrates. J Chem Ecol 23(6):1527-1545

Becerro MA, Uriz MJ, Turon X (1.994) Trends in space occupation by the encrusting sponge Crambe crambe: variation in shape as a function of size and environment. Mar Biol 121:301-307

Bergquist PR, Sincldir ME (1968) The morphology and behav- iour of larvae of some intertidal sponges. NZ J Mar Freshwat Res 2:426-437

Bibiloni MA (1990) Fauna de esponjas de las islas Baleares. Variación cualitativa y cuantitativa de la población de esponjas en un gradiente batimétrico. Comparación Baleares-Costa Brava. PhD thesis, Universitat de Barcelona

Bibiloni MA, Uriz MJ, Gili JM (1989) Sponge communities in three submarine caves of the Balearic Islands (western Mediterraneany: adaptation and faunistic composition. PSZN I: Mar Ecol 10:317-334

Bingham BL, Young CM (1991) Influence of sponges on invertebrate recruitment: a field test of allelopathy. Mar Biol 109:19-26

Boettcher AA, Targett NM (1996) [nduction of metamorphosis in queen conch, Strombus gigas Linnaeus larvae by cues associated with red algae from their nursery grounds. J Exp Mar Biol Ecol 196:29-52

Bonar DB, Coon SL, Walch M, Weiner RM, Fitt W (1990) Control of oyster settlement and metamorphosis by endogenous and exogenous chemical cues. Bull Mar Sci 46(2): $484-498$

Boury-Esnault N (1971) Spongiaires de la zone rocheuse littorale de Banyuls-sur-Mer. I. Ecologie et répartition. Vie Milieu 22:159-192

Boury-Esnault. N, Vacelet J (1994) Preliminary studies on the organization and development of a hexactinellid sponge from a Mediterranean cave, Oopsacas minuta. In: Van Soest RWM, Van Kempen TMG, Braeckman JC (eds) Sponges in time and space (biology, chemistry, paleontology). AA Balkema, Rotterdam, p 407-415

Burke RD (1986) Pheromones and the gregarious recruitment of marine invertebrate larvae. Bull Mar Sci 39:323-331

Butler AV (1986) Recruitment of sessile invertebrates at five sites in Gulf St. Vincent, South Australia. J Exp Mar Biol Ecol 97:13-36

Caley MJ, Carr MH, Hixon MA, Hughes TP, Jones GP, Menge BA (1996) Recruitment and the local dynamics of open marine populations. Annu Rev Ecol Syst 27:477-500

Carleton JH, Sammarco PW (1987) Effects of substratum irregularity on success of coral settlement: quantification by comparative geomorphological techniques. Bull Mar Sci 40(1):85-98

Carlon DB, Olson RR (1993) Larval dispersal distance as an explanation for adult spatial pattern in two Caribbean reef corals. J Exp Mar Biol. Ecol 173:247-263

Davis AR, Butler AJ (1989) Direct observations of larval dispersal in the colonial ascidian Podoclavella moluccensis Sluiter: evidence for closed populations. J Exp Mar Biol Ecol 127:189-203

Davis AR, Moreno CA (1995) Selection of substrata by juvenile Choromytilus chorus (Mytilidae): are chemical cues important? J Exp Mar Biol Ecol 191:167-180

Dayton PK (1979) Observations of growth, dispersal and population dynamics of some sponges in McMurdo Sound, Antarctica. In: Lèvi C, Boury-Esnault N (eds) Biologie des spongiaires. Sponge biology. CNRS, Paris, p 271-282

Eckman JE (1996) Closing the larval loop; linking larval ecology to the population dynamics of marine benthic invertebrates. J Exp Mar Biol Ecol 200:207-237

Elliot JM (1977) Statistical analysis of samples of benthic invertebrates. Freshwater Biological Association, Scientific Publication No. 25. Wilson \& Son Ltd, Kendal

Fell PE, Lewandrowski KB (1981) Population dynamics of the estuarine sponge Halichondria sp. within a New England eelgrass community. J Exp Mar Biol Ecol 55:49-63

Fell PE, Parry EH, Balsamo AM (1984) The life histories of sponges in the Mystic and Thames estuaries (Connecti- 
cut), with emphasis on larval settlement and postlarval reproduction. J Exp Mar Biol Ecol 78:127-141

Fry WG (1971) The biology of larvae of Ophlitaspongia serjata from two North Wales populations. In: Crisp DJ (ed) Proc 4 th Eur Mar Biol Symp. Cambridge University Press, London, p $155-178$

Grosberg RK (1987) Limited dispersal and proximity-dependent mating success in the colonial ascidian Botryllus schlosseri. Evolution 41:372-384

Hurlbut CJ (1992) Larval release and supply predict temporal variation in settlement of a colonial ascidian. Mar Ecol Prog Ser 80:215-219

Jackson JBC (1986) Modes of dispersal of clonal benthic invertebrates: consequences for species' distribution and genetic structure of local populations. Bull Mar Sci 39: $588-606$

Kaye HR (1990) Reproduction in West Indian commercial sponges: oogenesis, larval development and behaviour In: Rützler K (ed) New perspectives in sponge biology. Smithsonian Institution Press, Washington, DC, p 161-169

Keough $\mathrm{MJ}$, Chernoff $\mathrm{H}$ (1987) Dispersal and population variation in the bryozoan Bugula neritina. Ecology 68:199-210

Krebs CH (1989) Ecological methodology. Harper Collins Publishers, New York, NY

Levitan DR (1991) Influence of body size and population density on fertilization success and reproductive output in a free spawning invertebrate. Biol Bull 181:261-268

Lewin R (1986) Supply-side ecology. Science 234:25-27

Maida M, Coll JC, Sammarco PW (1994) Shedding new light on scleractinian coral recruitment. J Exp Mar Biol Eco] 180:182-202

Maldonado M, George SB, Young CM, Vaquerizo I (1997) Depth regulation in parenchymella larvae of a demosponge: relative roles of skeletogenesis, biochemical changes and behavior. Mar Ecol Prog Ser 148:115-124

Maldonado M, Young CM (1996) Effects of physical factors on larval behavior, settlement and recruitment of four tropical demosponges. Mar Ecol Prog Ser 138:169-180

Manly BFJ (1991) Randomization and Monte Carlo methods in biology. Chapman \& Hall, London

Martín D, Rosell D, Uriz MJ (1992) Harmothöe hyalonemae sp. nv. (Polychaeta, Polynoidae), an exclusive inhabitant of different Atlanto-Mediterranean species of Hyalonema (Porifera, Hexactinellida). Ophelia 35(3):169-185

Martín D, Uriz MJ (1992) Chemical bioactivity of Mediterranean benthic organisms agaunst embryos and larvae of marine invertebrates. J Exp Mar Biol Ecol 173:11-27

Maxwell SE, Delaney HD (1990) Designing experiments and analyzing data: a model comparison perspective. Wadsworth, Belmont, CA

Mead R (1974) A test for spatial patterns at several scales using data from a grid of contiguous quadrats. Biometrics 30:295-307

Meroz E, Ilan M (1995) Life history characteristic of a coral reef sponge. Mar Biol 124:443-451

Monsita M (1959) Measuring the dispersion of individuals and analysis of the distributional patterns. Mem Fac Sci Kyushu Univ, Ser E (Biol) 2:215-235

Osman RW, Whitlatch (1995) The influence of resident adults on larval settlement: experiments with four species of ascidians. J Exp Mar Biol Ecol 190:199-220

Pansini M, Pronzato R (1990) Observations on the dynamics of a Mediterranean sponge community. In: Rützler $\mathrm{K}$ (ed) New perspectives in sponge biology. Smithsonian Institution Press, Washington, DC, p 404-415

Pawlik JR (1992) Chemical ecology of the settlement of benthic marine invertebrates. Oceanogr Mar Biol Annu Rev
$30: 273-335$

Petersen J, Svane Y (1995) Larval dispersal in the ascidian Ciona intestinalis (L.). Evidence for a closed population. J Exp Mar Biol Ecol 186:89-102

Potvin C, Lechowica J, Tardif S (1990) The statistical analysis of ecophysiological response curves obtained from experiments involving repeated measures. Ecology 71(4): $1389-1400$

Pulitzer-Finali G (1983) A collection of Mediterranean demosponges (Porifera) with, in appendix, a list of the Demospongrae hitherto recorded from the Mediterranean Sea. Ann Mus Civ Stor Nat Genova 84:445-621

Reiswig HM (1973) Population dynamics of three Jamaican Demospongiae. Bull Mar Sci 23:191-226

Roughgarden J, Gaines SD, Pacala SW (1987) Supply-side ecology: the role of physical transport processes. In: Gie JHR, Giller PS (eds) Organization communities - past and present. 27th Symp British Ecological Soc, Aberystwyth, 1996. Blackwell, Oxford, p 491-518

Schmidt $O$ (1862) Die Spongien des Adriatischen Meeres. Wilhelm Engelmannn, Leipzig, p 1-88

Stoner DS (1994) Larvae of a colonial ascidian use a non-contact mode of substratum selection on a coral reef. Mar Biol 121:319-326

Strathmann RR (1974) The spread of sibling larvae of sedentary marine invertebrates. Am Nat 108:29-44

Svane I, Havenhand JN (1993) Spawning and dispersal in Ciona intestinalis (L.). PSZN I: Mar Ecol 14:53-66

Toonen RJ, Pawlik JR (1996) Settlement of the tube worm Hydroides dianthus (Polychaeta: Serpulidae) : cues for gregarious settlement. Mar Biol 126:725-733

Topsent E (1934) Eponges observées dans les parages de Monaco. $1^{\text {ere }}$ Partie. Bull Inst Océanogr Monaco 650:1-42

Tsurumi M, Reiswig HM (1997) Sexual versus asexual reprnduction in an oviparous rope-form sponge, Aplysina cauliformis (Porifera; Verongida). Invert Reprod Develop 32: $1-9$

Turon X, Becerro MA, Uriz MJ, Llopis J (1996) Small-scale association measures in epibenthic communities as a clue for allelochemical interactions. Oecologia 108:351-360

Turon X, Tarjuelo I, Uriz MJ (in press) Growth dynamics and mortality of the encrusting sponge Crambe crambe (Poecilosclerida) in contrasting habitats: correlation with population structure and investment in defence. Funct Ecol

Turon X, Vázquez E (1996) A non-swimming ascidian larva: Protostyela longicauda (Styelidae). Invert Biol 115(4): $331-342$

Underwood AJ (1981) Techniques of analysis of variance in experimental marine biology and ecology. Oceanogr Mar Biol Annu Rev 19:513-605

Underwood AJ, Chapman MG (1996) Spatial patterns of distribution of intertidal invertebrates. Oecologia 107: $212-224$

Underwood AJ, Fairweather PG (1989) Supply-side ecology and benthic marine ecology. Trends Ecol Evol 4:16-20

Uriz MJ (1982a) Morfología y comportamiento de la larva parenquímula de Scopalina lophyropoda Schmidt 1862 (Demospongia, Halichondrida) y formación del rhagon. Invest Pesq 42:313-322

Uriz MJ (1982b) Reproducción en Hymeniacidon sanguinea (Grant, 1926): Biología de la larva y primeros estadios postlarvarios. Invest Pesq 46:29-39

Uriz M.J, Becerro M, Tur JM, Turon X (1996a) Location of toxicity within the Mediterranean sponge Crambe crambe (Demospongiae: Poecilosclerida). Mar Biol 124:583-590

Uriz MJ, Rosell D, Martín D (1992) The sponge population of the Cabrera Archipelago (Balearic Islands): characteris- 
tics, distribution and abundance of the most representative species. PSZN I: Mar Ecol 13(2):101-117

Uriz MJ, Turon X, Becerro M, Galera J (1996b) Feeding deterrence in sponges. The role of toxicity, physical defenses, energetic contents, and life-history stage. J Exp Mar Biol Ecol 205:187-204

Uriz MJ, Turon X, Becerro MA, Galera J, Lozano J (1995) Patterns of resource allocation to somatic, defensive, and reproductive functions in the Mediterranean encrusting sponge Crambe crambe (Demospongiae, Poecilosclerida) Mar Ecol Prog Ser 124:159-170

Vacelet J (1996) Deep-Sea sponges in a Mediterranean cave. In: Viblein F, Ott J, Stachowitsch $M$ (eds) Deep-sea and extreme shallow-water habitats: affinities and adaptations. Biosystematics and ecology Series 11. Österreichische Akademie der Wissenschaften, Wien, p 299-312

Von Ende CN (1993) Repeated-measures analysis: growth and other time-dependent measures. In: Scheiner SM, Gurevitch $J$ (eds) Design and analysis of ecological experiments. Chapman \& Hall, London, p 113-137

Wapstra M, van Soest RWM (1987) Sexual reproduction, larval morphology and behaviour in demosponges from the southwest of the Netherlands. In: Vacelet J, Boury-Esnault

Editorial responsibility: Otto Kinne (Editor),

OIdendorf/Luhe, Germany
N (eds) Taxonomy of Porifera. NATO ASl Series 13. Springer-Verlag, Berlin, p 281-307

Woollacott R (1993) Structure and swimming behavior of the larva of Haliclona tubifera (Porifera: Demospongiae). J Morphol 218:301-321

Wulff JL (1985) Dispersal and survival of fragments of coral reef sponges. In: French Polynesian coral reefs: Proc 5th Int Coral Reef Congr. Antenne Museum-EPME, Moorea p $1.19-124$

Wulff JL (1991) Asexual fragmentation, genotype success and population dynamics of erect branching sponges. J Exp Mar Biol Ecol 149:227-247

Wulff JL (1995) Effects of a hurricane on survival and onentation of large erect coral reef sponges. Coral Reefs 14:55-61

Zar JH (1984) Biostatistical analysis. Prentice-Hall, Englewood Cliffs

Zea S (1992) Estimation of demosponge (Porifera, Demospongiae) larval settlement rates from short-term recruitment rates: preliminary experiments. Helgoländer Meeresunters 46:293-300

Zea S (1993) Recruitment of demosponges (Porifera, Demospongiaej in rocky and coral reef habitats of Santa Marta, Colombian Caribbean. PSZN I: Mar Ecol 14:1-21

Submitted: February 10, 1998; Accepted: April 3, 1998

Proofs received from author(s): June 8,1998 